\title{
EVIDENCE FOR A STRESS HYPOTHESIS: HEMIPARASITISM EFFECT ON THE COLONIZATION OF Alchornea castaneaefolia A. JUSS. (EUPHORBIACEAE) BY GALLING INSECTS
}

\author{
Gustavo SCHWARTZ ${ }^{1}$, Natalia HANAZAKI ${ }^{1}$, Marivana B. SILVA², Thiago J. IZZO ${ }^{3}$, \\ María E. P. BEJAR ${ }^{4}$, Mariana R. MESQUITA ${ }^{3}$, G. Wilson FERNANDES ${ }^{5}$
}

\begin{abstract}
Stressed plants are generally more attacked by galling insects. In this study we investigated the relationship between population abundance and species richness of galling insects on the tree Alchornea castaneaefolia A. JUSS. (Euphorbiaceae), submited to stress induced by the hemiparasite Psittacanthus sp. (Loranthaceae) in the Amazon, Brazil. Branches of $A$. castaneaefolia attacked by the hemiparasite were more heavily infested by galling insects than non-attacked branches. The field observations partially corroborate the hypothesis that there would be an optimal level of host-plant stress for galling insect establishment.
\end{abstract}

Key-words: Galling insects, Galls, Amazonian Rainforest, Stress, Host-plant Stress.

\section{Evidência para uma hipótese de estresse: o efeito do hemiparasitismo na colonização de Alchornea castaneaefolia A. Juss. (Euphorbiaceae) por insetos galhadores}

\begin{abstract}
RESUMO - Plantas estressadas geralmente são mais atacadas por insetos galhadores. Neste estudo investigamos a relação entre abundância populacional e a riqueza de espécies de insetos galhadores na árvore Alchornea castaneaefolia A. JUSS. (Euphorbiaceae), submetida ao estresse induzido pela hemiparasita Psittacanthus sp. (Loranthaceae) na Amazônia, Brasil. Galhos de $A$. castaneaefolia atacados pela hemiparasita foram mais fortemente infestados por insetos galhadores do que os galhos não atacados. As observações de campo corroboram parcilmente a hipótese de que haveria um nível ótimo de estresse da planta hospedeira para o estabelecimento de insetos galhadores.
\end{abstract}

Palavras-chave: Insetos galhadores, Galhas, Floresta Amazônica, Estresse, Estresse da planta hospedeira.

\section{INTRODUCTION}

Increase of galling insect species richness with increasing in environmental host-plant stress has been argued to be a global phenomenon, being particularly relevant for sclerophyllous vegetation (Fernandes and Price, 1988; Price et al., 1998). For instance Larrea tridentata Coult. (Zygophyllaceae) hosts support around 16 species of galling insects on the hottest and driest area of its geographical distribution, in southern Arizona, USA (Fernandes and Price, 1988; Warning and Price, 1990). Stressed plants in flooded environments are more susceptible to galling insects; therefore supporting this trend (Ribeiro et al., 1998).

\footnotetext{
${ }^{1}$ Graduate Program in Ecology, C.P. 6109, Universidade Estadual de Campinas, 13083-970 Campinas (SP) Brazil.

${ }^{2}$ Graduate Program in Biological Sciences, Universidade Federal do Pará, 66075-900 Belém (PA) - Brazil.

${ }^{3}$ Graduate Program in Ecology, C.P. 478, Instituto Nacional de Pesquisas da Amazônia, 69083-000 Manaus (AM) - Brazil.

${ }^{4}$ Colección Boliviana de Fauna, Instituto de Ecología, Casilla 10077 La Paz - Bolivia.

${ }^{5}$ Ecologia Evolutiva de Herbívoros Tropicais, C.P. 486, ICB Universidade Federal de Minas Gerais, 30161-970 Belo Horizonte (MG) - Brazil gwilson@icb.ufmg.br
} 
Similar patterns were observed at the species level of single species, where host individuals stressed by water and/or nutrients were more susceptible to attacks by gall inducers. Within one individual plant this phenomenon has also been reported, in which the parts of the plant exposed to sunlight are more heavily attacked than shadowed ones (Hartman, 1984; 1985; Fernandes and Price, in press). The basic question why host-plant stress would be advantageous for galling insects remains to be answered (but see Fernandes and Price, 1991).

A reasonable proposition is, that healthier hosts are less susceptible to galling due to stronger defenses. Under low stress condition, imposed primarily by water and nutrient shortage, a host plant would be able to improve rapid and efficient responses against galling insects (Fernandes, 1990). Moreover, plants under low stress could maintain a wider variety of natural enemies against gall inducers, such as other herbivorous insects that could compete for resources or act as predators, and even other natural enemies. Many insect herbivores prefer to attack fast growing plants or plant parts, therefore healthier hosts (see Price et al., 1990). On the other hand, plants under high stress would not be able to maintain gall inducers, because of processes of general decay or of enhanced senescence of their organs and tissues. Under unsuitable physiological conditions the chances for colonization and development of other herbivores would also be reduced (Gonçalves-Alvim et al., 2001). Thus, the highest richness and abundance of gall inducers might lie within an intermediate level of the spectrum of plant stress. Plants exposed to intermediate levels of water and/or nutrient stresses would offer an optimum to gall induction because lower resistance to galling combined with a lower probability of competition and attack by natural enemies (see Price et al., 1986). Intermediate levels of stress may not be strong enough to diminish the performance of the galling larvae, because galling insects are known to be able to drain plant resources far from the gall establishment point, thus improving the local conditions until complete larval development (Larrew, 1982; Rohfritsch, 1992).

In this work we suggested and tested the hypothesis that there would be an optimal level of stress at which induction and continued nutrition for the parasite larvae would be advantageous for galling species colonization (Fig. 1).
A

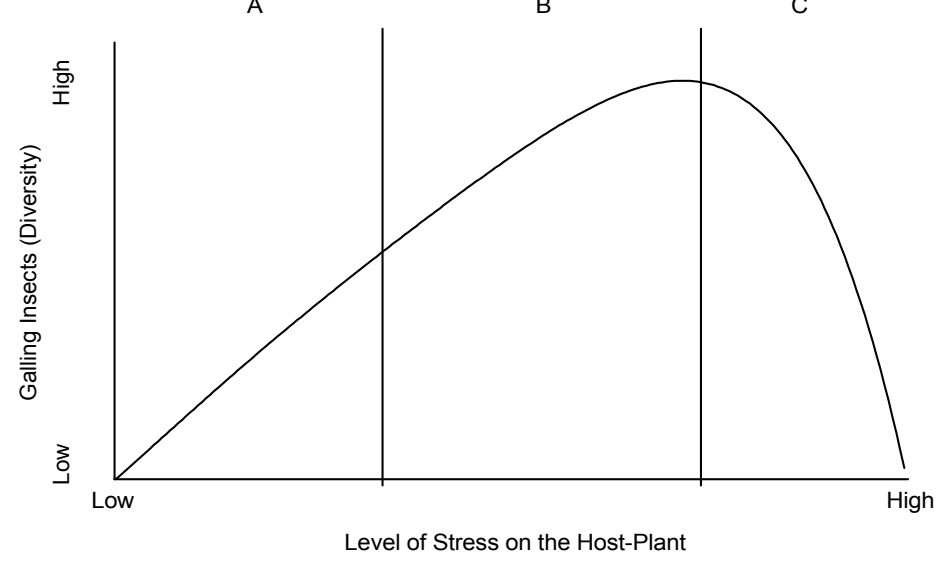

Figure 1 - A model for the "stress hypothesis": strong competition and host-plant defenses offer a low diversity (population abundance and species richness) of galling insects (A). A more profitable space for species richness and population abundance of galling insects is possible by an intermediate stress on host-plant that reduces its defenses and natural enemies against galling insects (B). Shortage of host-plant resources diminish the diversity of galling insects $(\mathrm{C})$. 


\section{MATERIAL AND METHODS}

To observe whether galling insects attack more stressed hosts or host organs, we studied the galling insect community on Alchornea castaneaefolia A. Juss. (Euphorbiaceae), a common tree species in the flood plains (várzeas) of the Solimões river (Amazonas, Brazil). Gall inducing insects are quite common on A. castaneaefolia at the Solimões river. This tree is also parasitized on branches by a species of Loranthaceae (Psittacanthus sp.), an hemiparasite. Casual observations indicate that the hemiparasitism by Psittacanthus induces some stress in host organs, easily observable as low growth and low biomass of colonized branches. Furthermore, reproduction of hostplant is also expect to diminish. We postulated that, although the insect parasite attack would affect the entire host tree, the impact by galling insects on the host-plant branch attacked by Psittacanthus sp. would be higher than on adjacent parasite-free branches. We observed this in all sampled individuals of $A$. castaneaefolia attacked by Psittacanthus sp. because attacked and nonattacked branches are found on the same host, thus the system is suitable for testing our hypothesis, which predicts that abundance and richness of galling insect (diversity) species would be higher on branches attacked by Psittacanthus sp. than on branches free of this hemiparasite.

The study was conducted in a "várzea" lake on the Ilha da Marchantaria $\left(03^{\circ} 14 \notin \mathrm{S}\right.$, $59^{\circ} 57 \mathrm{cW}$ ) in the Solimões river, at $15 \mathrm{~km}$ distance from its confluence with the Negro river (see Lovejoy and Bierregaard, 1991). Twentytwo individuals of Alchornea castaneaefolia attacked by Psittacanthus sp. were haphazardly selected along the "várzea" edges for this study. The distance between sampled trees was at least by 20 meters. On each tree we collected one branch of $A$. castaneaefolia colonized by Psittacanthus sp. and its closest branch without the hemiparasite. Galls were described and classified into four distinct morphotypes (Tab. 1). All galls were induced by undescribed species of Cecidomyiidae (Diptera). The number of leaves and insect galls found on each branch were counted and the number of galls was divided by the total number of leaves in each branch in order to minimize the effects of resource availability and area (abundance of leaves) on the abundance of galls. To compare abundance and species richness of insect galls on branches with and without Psittacanthus sp. we used one-tail paired $t$-test (Zar, 1999).

Table 1. Gall morphotypes found on individuals of Alchornea castaneaefolia at Ilha da Marchantaria, Amazonas, Brazil.

\begin{tabular}{lllll}
\hline & \multicolumn{4}{c}{ Gall Morphotype } \\
\cline { 2 - 5 } Shape & Gall 1 & Gall 2 & Gall 3 & Gall 4 \\
\cline { 2 - 5 } Host Organ & Leaf & Leaf & Stem/leaf & Leaf \\
Color & Yellow to green & Yellow & Green & Bright green \\
Wall Pilosity & Glabrous & Glabrous & Glabrous & Glabrous \\
No. of Chambers & One & One & Several & One \\
Leaf Surface & Both & Adaxial & - & Both \\
Coalescence & No & No & Yes & No \\
\hline
\end{tabular}




\section{RESULTS AND DISCUSSION}

There were no differences in galling species richness between branches of $A$. castaneaefolia with and without Psittacanthus sp. parasite. The four types of galls occurred with similar frequencies on both, parasitized and parasite-free branches of $A$. castaneaefolia by Psittacanthus sp. The mean ( $\pm 1 \mathrm{SE})$ of galls per leaf occurred at higher frequency on branches of $A$. castaneaefolia attacked by Psittacanthus sp. (2.04 \pm 0.45$)$ than on parasitefree branches $(1.27 \pm 0.21)$ showing a statistical difference $(\mathrm{t}=1.782 ; \mathrm{df}=21 ; \mathrm{P}<0.05)$.

Furthermore, the trend was influenced by two gall morphotypes that were most abundant on parasitized branches (Fig. 2): gall morphotype four was significantly more abundant on branches attacked by the hemiparasite $(\mathrm{t}=1.989 ; \mathrm{df}=21 ; \mathrm{p}<0.05)$, while the trend was marginally significant for gall morphotype three $(\mathrm{p}=0.064)$. The abundance of gall morphotypes one and two did not differ between branches with and without Psittacanthus sp.
The hypothesis predicted higher gall diversity and abundance on branches exposed to higher stress imposed on A. castaneaefolia by the hemiparasite. Our data corroborate only partially this hypothesis, because at the species richness level it was not supported. One possible explanation is that the number of galling insect species found was too low (only four types of galls) to allow for a reliable test of the hypothesis at the insect community level on A. castaneaefolia. At the population level the hypothesis was partially corroborated, from four species studied only two fitted the expected trend. Still, the study confirms that systems composed of plant parasites, host plants, and herbivores appears to offer a good scenario to test the hypothesis that stress of host trees due to the intensity of plant parasitism (i.e., relative density of branches attacked, parasite biomass, etc) influences the degree of insect parasitism because sampling manipulation is relatively easy. Future studies should expand this field of observation for a more strong experimental evidence.

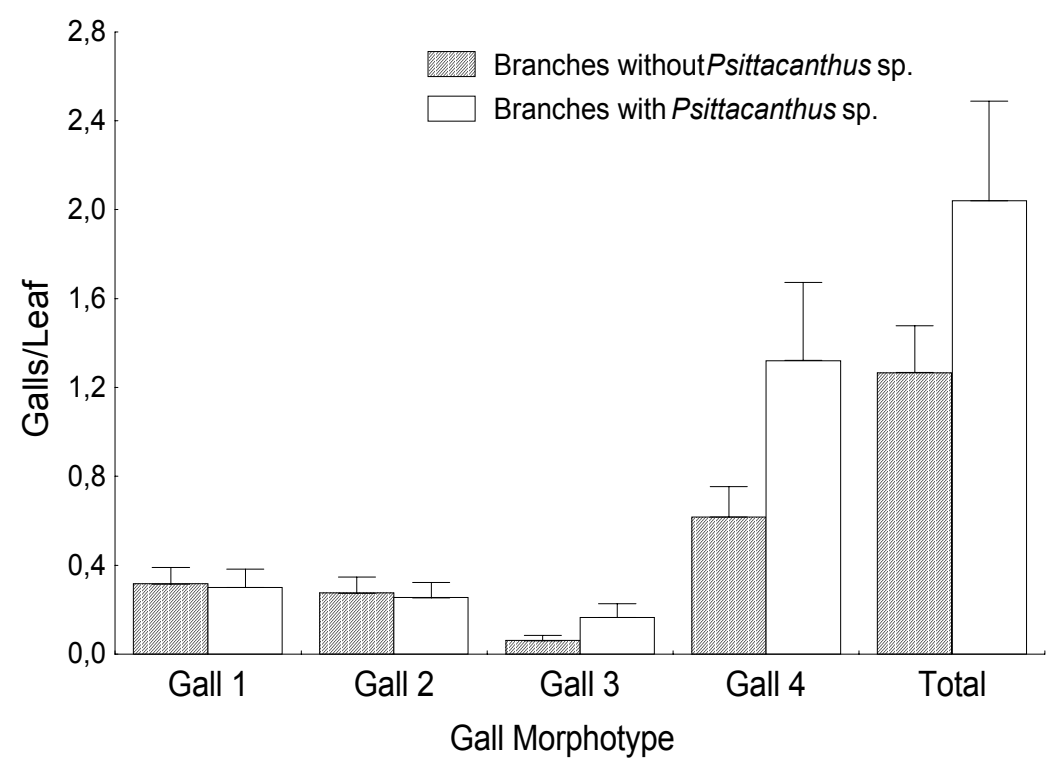

Figure 2. Distribution of the ratio galls/leaf (total number of galls per leaf in each branch) found on branches with and without Psittacanhus sp. on samples of 22 individuals of Alchornea castaneaefolia at Ilha da Marchantaria, Amazonas, Brazil. Error bars represent $1 \mathrm{SE}$ of the mean. 


\section{ACKNOWLEDGEMENTS}

This study was carried during the $8^{\text {th }}$ Field Course of Ecology of the Amazon Rainforest, supported by the Instituto Nacional de Pesquisas da Amazônia, the Smithsonian Museum, the Organization for Tropical Studies and the USDA. We are very grateful to Eduardo Venticinque, Mike Hopkins, and the referees for suggestions and revision. This is the publication 404 in the technical series of the Biological Dynamics of Forest Fragments project.

\section{LITERATURE CITED}

Fernandes, G.W. 1990. Hypersensibility: a neglected plant resistance mechanism against insect herbivores. Environmental Entomology, 19:1173-1182.

Fernandes, G.W.; Price, P.W. 1988. Biogeographical gradients in galling species richness: tests of hipotheses. Oecologia, 76:161-167.

Fernandes, G.W.; Price, P.W. 1991. Comparisons of tropical and temperate galling species richness: the roles of environmental hardness and plant nutrient status. In: Price, P.W.; Levinsohn, T.M.; Fernandes, G.W.; Benson, W.W. (Eds). Plant animal interactions: evolutionary ecology in tropical and temperate regions. Wiley \& Sons. New York, USA. p.91-115.

Fernandes, G.W.; Price, P.W. (in press). Selection forces shaping galling sucess among and within habitats. Oecologia.

Gonçalves-Alvim, S.J.; Santos, M.C.F.V.; Fernandes, G.W. 2001. Leaf gall abundance on Avicennia germinans (Avicenniaceae) along an interstitial salinity gradient. Biotropica, 33:69-77.

Hartman, H. 1984. Ecology of gall-forming Lepidoptera on Tetradymia. Hilgardia, 52:17-27.

Hartman, H. 1985. Differential intensities of gall insect infestation among host plant size classes: outbreak frequency estimation model. Z. Angew. Entomol., 99:329-332.

Larrew, H. 1982. A comparative anatomical study of galls caused by the major cecidogenic group, with special emphasis on the nutritive tissue. PhD Dissertation, Oregon State University, Corvallis, USA. $101 \mathrm{p}$.

Lovejoy, T.E.; Bierregaard, R.O. 1991. Central Amazonian forest and the minimal critical size of ecosystem project. In: Gentry, A. H. (Ed). Four neotropical rainforests. Yale University Press, New Haven, USA. p.60-71.

Price, P.W.; Cobb, N.; Craig, T.P.; Fernandes, G.W.; Itami, J., Mopper, S.; Preszler, R.W. 1990. Insect herbivore population dynamics on trees and shrubs: new approaches relevant to latent and eruptive species and life table development. In: Bernays E.A. (Ed). Focus on insect-plant interactions. Vol. 3. CRC books, Boca Raton, Florida, USA. p.1-38.

Price, P.W.; Fernandes, G.W.; Lara, A.C.F.; Brawn, J.; Gerling, D.; Barrios, H.; Wright, M.G.; Ribeiro, S.P.; Rothcliff, N. 1998. Global patterns in local number of insect galling species. Journal of Biogeography, 25:581-592.

Price, P.W.; Webstoby, M.; Rice, B.; Astatt, P.R.; Fritz, R.S.; Thompson, J.N.; Mobley, K. 1986. Parasite mediation in ecologiacl interactions. Annual Review of Ecology and Systematics, 17: 487-505.

Ribeiro, K.T.; Madeira, J.A.; Monteiro, R.F. 1998. Does flooding favour galling insects? Ecological Entomology, 23:491494.

Rohfritsch, O. 1992. Patterns in gall development. In: Shorthouse, J.D.; Rohfritsch, O. (Eds.). Biology of insect-induced galls. Oxford University Press. New York, USA. p.60-82.

Warning, G.L.; Price, P.W. 1990. Plant water stress and gall formation (Cecidomyiidae: Asphondylia spp.) on creosote bush. Ecological Entomology 15: 87-95.

Zar, J.H. 1999. Biostatistical analysis. Prentice-Hall, New Jersey, USA. 663p.

\section{Recebido: 19/02/2002}

Aceito: 11/02/2003 
